Kohl: a Journal for Body and Gender Research Vol. 6, No. 1 (Summer 2020)

\title{
Seven Analytical Recommendations for the (Un)Queer-(y)ing of the Middle East
}

Sabiha Allouche 
In a timely and succinct intervention, Maya Mikdashi and Jasbir Puar (2016) invite us to embrace the Middle East as queer seeing its "permanent war" status. They investigate the links between queer theory and areas studies and ponder the "kind of queer" that emerges in the face of "permanent war" (Ibid:219). Both authors lament the strand of queer scholarship whereby the global south is "reified as raw data" (Ibid:215) to be queried whilst referring it, sooner or later, to Anglo-American queer scholarship.

Mikdashi and Puar successfully relegate queer theory to the area of the Middle East without jeopardizing nor denying the activism-ridden core of its Anglo-American roots all the while maintaining the specificity of queer experiences elsewhere and the theoretical benefits of thinking of particular areas as queer - "Queer Theory as Area Studies" (Ibid:216). Among the interrogations they put forth in their endeavor to overcome such epistemological impasses, they ask:

What animates the impulse to search for something to call or to theorize as queer? What must the queer body do, or be, to be recognized as such, and by whom? Do we want this recognition, and if so, how and for what purposes? (Mikdashi and Puar 2016:219)

This short essay ${ }^{1}$ contributes to the conversation put forth by Mikdashi and Puar. Its larger purpose is to intellectually evaluate the consequence of the increased visibility of the Middle East as an object of investigation in English-speaking cultural, literary and scholarly narratives, a state of affairs I call outerqueer-(y)ing. By outer-queer-(y)ing, I mean the forced and artificial subjugation of the fictive category of the Middle East to a queer analysis that is informed, shaped and delimitated by a US experience. Outer queer-(y)ing is both (dis)orientating and "Orientalizing" (Said 1978). That is, its dealing with the "queer" orients it towards US queer scholarship whilst reinforcing orientalist depictions of the "other." The uneventful outcomes of this (dis)orienting is four-fold:

a. It privileges the theoretical scope of queer theory itself, rather than the context in question;

b. Its preoccupation with the question of queer visibility in the Middle East analytically demotes the latter's heterogeneity;

c. It overlooks the relevance of gender performativity in episodes of sexual dissent in the Middle East, be it in a heterosexual or a non-heterosexual context;

d. The universalization of gay rights leads to a Euro-American binary assessment of sexuality as either "perverted" or "normal" (Weber 2016); either "bad" or "good" (Rubin 1984).

I draw hereafter seven inevitable pitfalls of an outer-queer-(y)ing exercise. My list is not exhaustive and does not pretend to offer full closure to the conundrum in place. It does, nevertheless, bring to the surface important links that conventional political analysis would easily miss:

\section{Sexed colonial legacies}

1 This paper was first presented during the Sexuality and Borders Symposium, at NYU, 4-5- April 2019. 
2. The limits of European secularism

3. The racialization of homophobia aka gay-friendly Islamophobia

4. The epistemic violence of Gay Internationalists

5. The disregard for "sexual practice and gender performance"

6. The heterosexuality of the modern Arab state

7. The accelerated sectarianisation of the Middle East

\section{Sexed colonial legacies}

Seen from a Euro-American grasping of sexuality, the intersection of Islam with sexuality produces the Muslim other as a barbaric whose sexuality, understood to be deviant, unattainable, and enigmatic, ought to be tamed. Critical scholars who work on gender and sexuality in the Middle East pay attention to the long-lasting legacies of colonialists' depictions of, and interactions with colonized/brown bodies by uncovering the reductionist and orientalist views that informed colonial rule (Najmabadi 2005; Ze'evi 2006; Habib 2010; Amer 2012). In his paradigm-shifting work, Orientalism, Edward Said (1978:1-2) states:

The Orient was almost a European invention, and had been since antiquity a place of romance, exotic beings, haunting memories and landscapes, remarkable experiences.

Although Said laid the foundation for orientalism as an analytical tool, he did not examine sexuality per se. He did, nevertheless, stress the overall "feminine" character of the Orient: "its [the Orient] riches as fertile, its main symbols the sensual woman, the harem, and the despotic - but curiously attractive - ruler" (Said 1978:225). Further authors built on the work of Said in order to show how the orientalist gaze constructs nonwestern exotic others. Yeğenoğlu (1998), for instance, argues that in order to understand the "sexualized nature of Orientalism," we ought to examine its "unconscious structure" (Yeğenoğlu 1998:2). During colonial times, Middle East women's bodies served as a visual vehicle for the consolidation of orientalist fantasies (Alloula 1987; Grewal 1996). The extent of this projection is still relevant in what Leila Ahmad (1993) calls "colonial feminism" and more recently, Lila Abu-Lughod (2013) famously asked: do Muslim women need saving? Arab men, too, have and continue to be Orientalized along feminized, and hypersexual and hypermasculine assumptions (Boone 2014; Hopwood 1999; McCormick 2011).

\section{The Limits of European Secularism}

Gender and sexuality aside, one enduring colonial legacy is the conflation of Arab-ness with Islam and monolithically interpreting the latter. In her critical reading of European diversity, Fatima El-Tayeb (2012:268) reminds us that: 
The framing of Islam not only as a "social order" dictating every aspect of the life of every Muslim, but as an order incompatible with, if not actively opposing, "European values" of tolerance and democracy has been thoroughly mainstreamed.

This framing is highly reductive. Not only does it instill a sanitized view of Islam as a vacuous concept, Islam's very intersectionality with nationality, ethnicity, race, gender, class, migration, and further social and political categories is blatantly discounted. This sanitized view partly allows the US to assert a self-professed form of "exceptionalism" that works "as a missionary discourse to rescue Muslim women (and homosexuals) from their counterparts" (Puar 2007:4) (my addition).

What's more, with the presumption that the "secular west" is a pre-condition for sexual emancipation (Farris 2017; Scott 2018), how do we account for the simultaneity of both categories, i.e. Muslim and nonheterosexual? On this point, Abeera Khan (2020:137) rightly urges us to confront the myth of "queer secularity" by showcasing the complicity of critical secularism studies in the "increased instrumentalization of queer subjectivities and queer collusions" in Europe and elsewhere.

\section{The Racialization of Homophobia aka Gay-Friendly Islamophobia}

Following Jasbir Puar (2007), the events of 9/11 led to the incorporation of an "acceptable" form of homosexuality in the US' national fold. The recognition of gay heroism by the Bush administration de facto endorses specific homosexualities that sustain and reproduce America's exceptionalism "through gendered, racial, and class-sanitizing in order to produce 'monster-terrorist-fags'; homosexuals then embrace the usversus-them rhetoric of US patriotism" (46). Consequently, the US' self-professed "exceptionalism" is henceforth "joined by an exceptional form of national homonormativity, in other words, homonationalism" (Ibid:2). In particular, homonationalism relocates homophobia from US heteronormative administration and citizens onto foreign others, notably brown and Muslim bodies. The entanglement of sexuality within the US nation produces assemblages of unequal citizens, some more respectable than others. This newly incorporated homosexuality is dependent upon the ethnic and racialized demarcation of newly-designated allegedly homophobic Muslim others.

Whereas Puar (2007) demonstrates the structural transformation of homophobic discourse in the US following $9 / 11$, i.e. homonationalism, Weber (2016) explores the ramifications of this novel order in light of the universalization of "gay rights." For the US to maintain its exceptionalism henceforth, it must lay the ground for a homosexuality that is not only acceptable, but also normalized. That is, for the "normal homosexual" to emerge, a "perverse homosexuality" must be made visible.

In her 2016 work, Queer International Relations, Weber (2016) distinguishes between the "perverse homosexual" and the "normal homosexual" in her examination of the interplay between sexuality, immigration, and security. Weber (2016) inspects the enmeshment of sovereignty with sexuality, race, and (im)migration on a global scale in order to show how the "modern sovereign man," whose sexuality is 
understood as normal, is produced against a myriad of others and their derivatives, including the "normal homosexual," the "perverse homosexual," the "gays rights holder," the "terrorist," and the "unwanted $\mathrm{im} /$ migrant." These seemingly unrelated systems can be assembled in a myriad of (often inconsistent) ways for the purpose of accommodating US interests. In order to conceptualize the range of assemblages that ensue from the derivative-other' relation(s) to the "sovereign man," Weber (2016:53) deploys two broad concepts, the "underdeveloped" and the "undevelopable." Both concepts are tools aimed at measuring the potential of the sovereign man's derivative-others' to develop mentally, emotionally, socially, economically, industrially, and politically, according to and following western onto-epistemological truths:

The "West" figures the "underdeveloped" and the "undevelopable" as perversions in/of their conceptualization of evolutionary time. (lbid)

Weber's analysis clearly captures what I term "gay-friendly islamophobia," or the "anomalous" status that uncritical Euro-American understandings of sexuality ascribe onto Muslim non-heterosexuals residing in the Middle East. This anomaly arises from their Muslim and else status. Whereas the Muslim non-heterosexual individual is wrongly presumed to be incapable of wholly embracing their sexuality unless relocated to a western setting, their Muslim status renders them unwelcomed.

\section{The Epistemic Violence of Gay Internationalists}

In the context of the Middle East, Joseph Massad (2007) argues that privileged Western LGBT activist groups, which he terms "Gay International," force an alien lexicon of sexuality. Following Massad (2007), the orientalist foundations of "Gay Internationalists" logic is captured in their imposition of a singular understanding of a sexuality predicated upon Euro-American histories and social formations. Indeed, a EuroAmerican understanding of sexuality is oblivious to the specificity of the violence that accompanies Middle East LGBT individuals' experiences of "coming out of the closet." In the context of Palestine, for instance, Jason Ritchie (2010) shows how the "Israeli checkpoint," rather than "the closet," shapes the strategies of Arab self-identified queers. Moreover, a Euro-American understanding of sexuality conflates sexual behavior with sexual identity, or as akshay khanna puts it, "who I fuck or am attracted to says something about the type of person I am" (khanna 2007, cited in Rao 2014:176). Rahul Rao argues that "this distinction has made it possible to assert both the universality of homosexual behavior and the cultural specificity of sexual minority identities" (lbid). What remains absent from this conflation are locally-informed material (D'Emilio 1983), historical (Foucault 1990), migratory (Manalansan 2006), and bio-political (Haritaworn et al. 2014) processes that contribute to shaping discourses of desire and sexuality.

However, it is important that we acknowledge the "ugly" doings of theory in our work and to remedy the sometimes detrimental impact of Massad's work on the study of sexuality in the region. Whereas it is important that we acknowledge Massad's attempt to horizontally engage with the figure of the queer in the Middle East, notably his critique of the universalization of the western homosexuality experience, his analysis inadvertently reiterates outer-queer(y)ing for two reasons. Theoretically, and rather than embracing the 
already queer status of the Middle East, Massad reads Middle East homosexuality in relation to, and whilst referring it back to queer theory in the Anglo-American sense. Empirically, his work has been criticized by self-identified homosexuals from the region, many of whom consider his observations to be contrary to their personal beliefs and individual experiences (Makarem 2011; Hamdan 2015).

\section{The Disregard for "Sexual Practice and Gender Performance"}

Labelling aside, a Euro-American understanding of sexuality is oblivious to the bearing of gender, on sexual dissidence in the Middle East, as Nof Nasser-Eddin, Nour Abu-Assab and Ayden Greatrick (2018) rightly show. That is, failure to embody societal expectations related to male and female behavior (for example, masculine women, or feminine men) could and does result in jeopardy. Sexual orientation becomes almost secondary to gendered performance. Conversely, it is futile that we think sexuality irrespective of gender, and vice versa, in the Middle East and everywhere. Moreover, and contrary to the assumption that non-heterosexuality and Islam are incompatible, the recent literature successfully demonstrates how a my riad of "tactics, issues, and modalities of sexual dissent" have shifted the conversation from the question of visibility of non-heterosexual Muslim lives, to highlighting its links with "overlapping projects of freedom," including "gender, kinship, citizenship, and property" (lonnides 2014:117).

\section{The Heterosexuality of the Modern Arab state}

The turn of the $20^{\text {th }}$ century equated heterosexuality with good citizenship in the west (2004) and in the Middle East (Abu-Lughod 1998; Hayes 2000; Najmabadi 2005; Ze'evi 2006). For the contemporary Middle East ruling-class, heterosexual modernity as a model of governance allows them to absorb the highly hybrid (read gendered, sexed, classed, and racialized) political aspirations of their societies, characterized by a "continuum," as opposed to a binary, between the religious and secular poles (AlAli 2000), and where each selectively repudiates and chooses from the other's repertoire (AbuLughod 1998). Outside of the Middle East, the events of 9/11 brought forth what Bryan Turner (2007) terms the "management of Muslims," a sous entendu for multiculturalism. This (mis)management portrays the Muslim other as generally lacking in development. Where sexuality is concerned, there is little that distinguishes the non-heterosexual, from the heterosexual, or the homosexual Muslim, evident in the racialized, classed, and gendered assemblages that homonationalism commands.

\section{The Accelerated Sectarianisation of the Middle East}

Sexuality aside, the accelerated sectarianisation of the Middle East, namely the Sunni/Shi'a rift, characterized by the current US-Saudi rapprochement and the US' withdrawal from the Iranian Nuclear deal, reproduces it, yet again, as incapable of self-governance. The sectarianisation of the 
Middle East is but an extension of colonialists' divide-and-rule tactics. On this note, historian Usama Makdisi (2017:7-8) reminds us that:

The idea of an innate Middle Eastern or Islamic sectarianism often serves to absolve Western powers form their complicity in creating, encouraging, or exacerbating a sectarianized political landscape in the Middle East.

Makdisi is contesting the words of ex-US president Barack Obama who, in his final State of Union address, stated that "the only organizing principles [in the region] are sectarian" and that "the conflicts that rage in the Middle East under America's watch date back millennia" (Ibid). The myth of a millennia-old sectarian rivalry in the region constructs (Muslim) others at each of the local, global, and transnational levels and upholds their "developability," to reiterate Weber (2016). In addition, it ignores the direct links between the "debilitating" and "maiming" biopolitics-outcomes of the Global War on Terror, and the "sexualized, gendered, classed, and racialized transnational discourses about Islam, Arab, and the Middle East" (Mikdashi and Puar 2016:221). Where the question of Islam is concerned, one can discern a shift from "all Muslim men are terrorists," to "some Muslim men are terrorists, depending on where they stand vis-à-vis US foreign policy." In the first stance, and as I argued earlier, Muslim sexuality is deployed as an object of fear to be queried and evaluated; in the second case, Muslim sexuality acquires a culturally relativist meaning where the otherness of the other is protected in order to maintain pre-existing power dynamics.

So how do we unknot this cacophony on entangled tropes? I propose (un)-queer-(y)ing non-binary, and in many ways though not exclusively, rectifying exercise. It is a methodology that recognizes the plurality of queerness because it recognizes that a US queer experience is one example of state-society negotiations vis-à-vis sexuality. Analytically speaking, inner queer-(y)ing, or a pluralistic understanding of queer methodology showcases the analytical gains to be made from it: the multiple starting points of queer narratives, their multiple trajectories, and our multiple conclusions as researchers, activists and intellectually curious readers. Most importantly, to think the multiple trajectories of queering, is to recognize its decolonizing potential, as shown by Walaa Alqaisiya (2020) in her re-reading of settler-colonialism in the context of Palestine. Ultimately, (un)-queer-(y)ing is a fluid yet lengthy exercise that pinpoints the immediate violences that ensue from an "either/or" logic (Weber 2016) of our world. 
Kohl 6.1

\section{References}

Abu-Lughod, L. 1998. Remaking Women: Feminism and Modernity in the Middle East. Princeton: Princeton University Press.

Abu-Lughod, L. 2013. Do Muslim Women Need Saving? Cambridge: Harvard University Press.

Ahmad, L. 1993. Women and Gender in Islam: Historical Roots of a Modern Debate. New Haven and London: Yale University Press.

Al-Ali, N. 2000. Secularism, Gender and the State in the Middle East: The Egyptian Women's Movement. Cambridge: Cambridge University Press.

Alloula, M. 1987. The Colonial Harem. Manchester: Manchester University Press.

Alqaisiya, W. 2020. "Palestine and the will to theorise decolonial queering." Middle East Critique 29(1): 87113.

Amer, S. 2012. "Naming to empower: lesbianism in the Arab Islamicate world today." Journal of Lesbian Studies 1(4): 381-397.

Boone J. A. 2014. The Homoerotics of Orientalism. New York: Columbia University Press.

D'Emilio, J. 1983. "Capitalism and Gay identity." in A. Snitow, C. Stansell, and S Thompson, eds., Powers of Desire: The Politics of Sexuality. New York: Monthly Review Press.

El-Tayeb, F. 2012. "'Gays who cannot properly be gay': queer Muslims in the neoliberal European city." European Journal of Women's Studies 19(1): 79-95.

Farris, S. R. 2017. In the Name of Women's Rights: The Rise of Femonationalism. Durham: Duke University Press.

Foucault, M. 1990. The History of Sexuality: An Introduction, transl. by R. Hurley. New York: Pantheon Books Grewal, I. 1996. Home and Harem: Nation, Gender, Empire, and the Cultures of Travel. Durham, NC: Duke University Press.

Habib, S. 2009. Islam and Homosexuality. Santa Barbara: ABC-CLIO.

Hamdan, S. 2015. "Re-orienting desire from with/in queer Arab shame: conceptualizing queer Arab subjectivities through sexual difference theory in a reading of Bareed Mista3jil." Kohl: A Journal for Body and Gender Research 1 (1): 54-69.

Haritaworn, J., A. Kuntsman and S. Posocco. 2014. Queer Necropolitics. Oxon: Routledge.

Hayes, J. 2000. Queer Nations: Marginal Sexualities in the Maghreb. Chicago and London: Chicago University Press.

Hopwood, D. 1999. Sexual Encounters in the Middle East: The British, the French, and the Arabs. Reading, UK: Ithaca.

Inonnides, G. 2014. "Queer travels: intersections for the study of Islam, sexuality, and queer theory." In Queering Religion, Religious Queers, edited by Y. Taylor and R. Snowdon, 117-136. New York and London: Routledge.

Khan, A. 2020. "Queer Secularity." Lambda Nordica 25(1): 133-139.

Makarem, G. 2011. "The Story of Helem." Journal of Middle East Women's Studies 7(3): 98-112.

Makdisi, U. 2017. "The mythology of the sectarian Middle East." Rice University's Baker Institute for Public Policy. Available at https://www.bakerinstitute.org/media/files/files/5a20626a/CME-pubSectarianism-021317.pdf. Accessed 22 June 2020. 
Manalansan IV, M. 2006. "Queer intersections: sexuality and migration in queer studies." The International Migration Review 40 (1): 223-249.

Massad, J. 2007. Desiring Arabs. Chicago, IL: Chicago University Press.

McCormick, J. 2011. "Hairy chest, will travel: tourism, identity, and sexuality in the Levant." Journal of Middle East Women's Studies 7(3): 71-97.

Mikdashi, M and Puar, J. K. 2016. "Queer theory and permanent war." GLQ: A Journal of Lesbian and Gay Studies, 22(2): 215-22.

Najmabadi, A. 2005. Women with Moustaches and Men Without Beards: Gender and Sexual Anxieties of Iranian Modernity. Berkeley: University of California Press.

Nasser Eddin, N., Abu-Assab, N and A. Greatrick. 2018. "Reconceptualising and contextualizing sexual rights in the MENA region: beyond LGBTQI Categories." Gender \& Development 26 (1): 173-189.

Puar, J. K. 2007. Terrorist Assemblages: Homonationalism in Queer Times. Durham: Duke University Press.

Rao, R. 2014. "The Locations of homophobia." London Review of International Law 2(2):169-199.

Ritchie, J. 2010. "How do you say 'come out of the closet' in Arabic? Queer activism and the politics of visibility in Israel-Palestine." GLQ: A Journal of Lesbian and Gay Studies 16 (4): 557-575.

Rubin, G. 1984. "Thinking sex: notes for a radical theory of the politics of sexuality." in Peter Aggleton and Richard Parker (eds), Culture, Society and Sexuality: A Reader. Oxon and New York: Routledge.

Said, E. W. 2006. Orientalism. New York: Vintage Books.

Scott, J. W. 2018. Sex and Secularism. Princeton: Princeton University Press.

Turner, B. 2007. "Managing Religions: State Responses to Religious Diversity." Contemporary Islam 1(2): 123-137.

Weber, C. 2016. Queer International Relations: Sovereignty, Sexuality and the Will to Knowledge. Oxford: Oxford University Press.

Yeğenoğlu, M. 1998. Colonial Fantasies: Towards a Feminist Reading of Orientalism. Cambridge: Cambridge University Press.

Ze'evi, D. 2005. Producing Desire: Changing Sexual Discourse in the Ottoman Middle East, 1500-1900. Berkeley: University of California Press. 